\title{
Juxtacortical Hemorrhage in Cerebral Venous Thrombosis: Cashew Nut Sign
}

\author{
Serebral Venöz Trombozda Jukstakortikal Hemoraji, Kaju Bulgusu
}

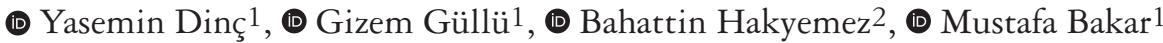 \\ 1 Uludag University Faculty of Medicine, Department of Neurology, Bursa, Turkey \\ 2Uludag University Faculty of Medicine, Department of Radiology, Bursa, Turkey
}

Keywords: Cerebral venous thrombosis, juxtacortical hemorrhage, trolard vein thrombosis

Anahtar Kelimeler: Serebral venöz tromboz, jukstakortikal hemoraji, trolard ven trombozu

Dear editor,

Cerebral venous sinus thrombosis (CVST) is incorrectly diagnosed and treated due to clinical heterogeneity and various etiological factors. Diagnosis is only possible with good clinical skills and a high degree of suspicion and interpretation of the radiological image. Presented herein is a 20-year-old male patient with non-traumatic juxtacortical hemorrhage $(\mathrm{JCH})$ and CVST. He was presented to the emergency department as he experienced weakness on his right side. His neurological examination revealed consciousness, with right central facial paralysis, right hemiplegia, and global aphasia. The cranial computed tomography revealed 2-3 $\mathrm{mm} \mathrm{JCHs}$ in the left frontoparietal region (Figure 1A, B). The cranial magnetic resonance imaging that was performed 24 $\mathrm{h}$ later revealed a hemorrhage in the cortical and subcortical areas of the left frontoparietal region, diffuse edema, and approximately $1 \mathrm{~cm}$ of subfalcian herniation in the midline structures (Figure 1C). Venous magnetic resonance angiography did not detect left frontal Trolard veins in the lesion area (Figure 1D). Laboratory tests revealed low levels of vitamin B12 and folic acid and a high level of homocysteine $(322 \mu \mathrm{mol} / \mathrm{l})$. With hyperhomocystinemia diagnosis, vitamins B1-B6-B12 and folic acid and low molecular weight heparin were initiated. The patient was being followed during the first year since the onset of the symptom with a good clinical outcome.

Intracranial hemorrhage occurs in approximately $40 \%$ of the patients with CVST, and non-traumatic JCH is associated with CVST. JCHs occur in the white matter, and when they are located close to the cortical sulcus, they cause a concave shape resembling

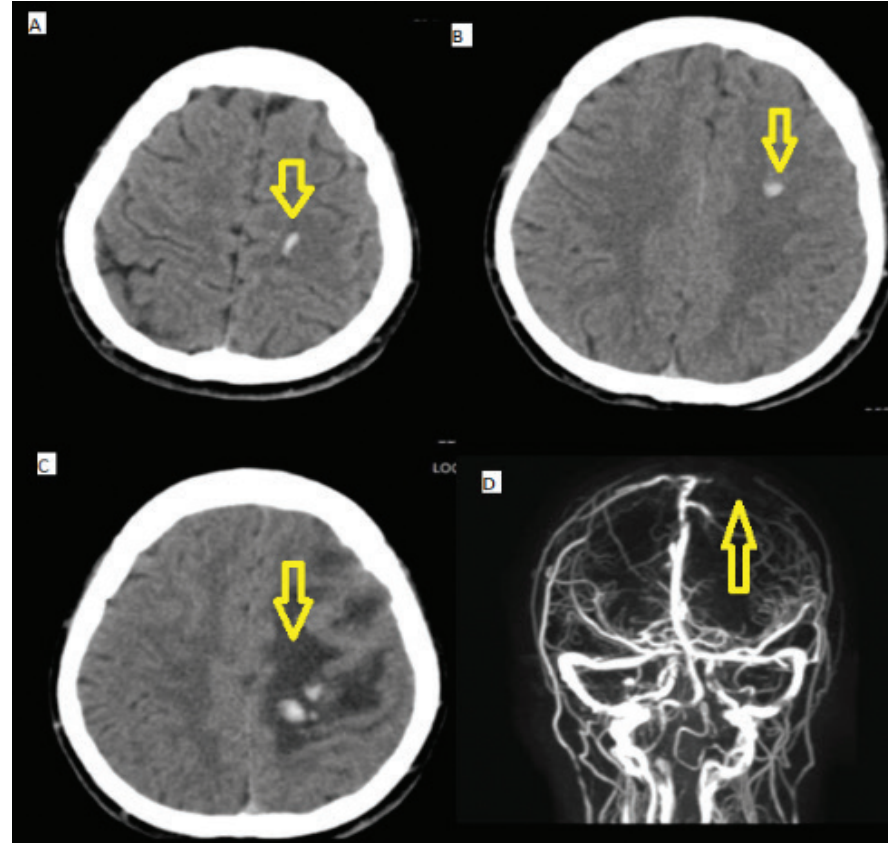

Figure 1. (A, B) Juxtacortical hemorrhages of $2-3 \mathrm{~mm}$ in the left frontoparietal region. (C) Hemorrhage in the cortical and subcortical areas in the left frontoparietal region and diffuse edema. (D) The left frontal Trolard veins were not detected in venous magnetic resonance angiography (thrombosis)

Address for Correspondence/Yazışma Adresi: Yasemin Dinç MD, Uludag University Faculty of Medicine, Department of Neurology, Bursa, Turkey Phone: +905301790512 E-mail: yaseminden87@hotmail.com ORCID: orcid.org//0000-0003-0342-5939 Received/Geliş Tarihi: 24.06.2020 Accepted/Kabul Tarihi: 16.05 .2021

${ }^{\circ}$ Copyright 2021 by Turkish Neurological Society

Turkish Journal of Neurology published by Galenos Publishing House 
a cashew nut (1). The venous drainage of the brain is anatomically divided into deep and superficial (2). Blood is collected in the subcortical and intracortical vessels and is then transported from the pial to the cortical veins. Cortical veins drain into the superior sagittal sinus. The drainage area of the subcortical vessels coincides with the location of the JSCs, and the subcortical vessels are divided into 3 parts, one of which is a curved segment (3). The subcortical vessels, which are curved, run parallel to the curved fibers (U-fibers) in the white matter and thus follow the curvature of the cortex, similar to JCHs. Both the location and shape of the JCHs coincide with the arcuate segments of the subcortical vessels. Thus, an anatomical source of JCHs appears in the CVST. Superior sagittal sinus thrombosis causes superficial venous drainage disruption of the brain, which causes increased pressure in the more proximal veins. According to some authors, JCH occurs since the arcuate segments of the subcortical vessels are anatomically different from other parts of the superficial drainage system and are more susceptible to rupture in response to increased pressure, or that vessels in the cortex are more resistant to rupture because the cortex itself is responsible for the increased pressure within the vessels. It has a denser structure that can provide resistance to pressure. Contrarily, the white matter has a looser structure, and vessels in the white matter, the weakest structure in the superficial venous system, are most susceptible to rupture (4).

In a rat CVST model, the size of the venous collateral circulation was shown as an important factor in determining whether superior sagittal sinus occlusion causes parenchymal damage (5). The smaller the size of the venous collateral circulation, the higher the probability of rupture due to superior sagittal sinus thrombosis. The cashew sign is a new radiological finding with relatively high CVST specificity. Cashew sign was associated with superior sagittal sinus thrombosis in previous studies; however, the patient had Trolard vein thrombosis without superior sagittal sinus thrombosis, unlike the literature. Clinicians should be aware that patients with non-traumatic JCH are mostly diagnosed with CVST.

\section{Ethics}

Informed Consent: Informed consent was applied.

Peer-review: Externally and internally peer-reviewed.

\section{Authorship Contributions}

Surgical and Medical Practices: Y.D., G.G., M.B., Concept: Y.D., Design: Y.D., B.H., Data Collection or Processing: Y.D., B.H., Analysis or Interpretation: Y.D., G.G., B.H., M.B., Literature Search: Y.D., Writing: Y.D., G.G.

Conflict of Interest: No conflict of interest was declared by the authors.

Financial Disclosure: The authors declared that this study received no financial support.

\section{References}

1. Ferro JM, Canhao P, Stam J, et al. Prognosis of cerebral vein and dural sinus thrombosis; results of the International Study on cerebral vein and dural sinus thrombosis (ISCVT). Stroke 2004;35:664-670.

2. Pearl M, Gregg L, Gandhi D. Cerebral venous development in relation to developmental venous anomalies and vein of Galen aneurysmal malformations. Semin Ultrasound CT MR 2011;32:252-263.

3. Okudera T, Huang YP, Fukusumi A, et al. Micro-angiographical studies of the medullary venous system of the cerebral hemisphere. Neuropathology 1999;19:93-111.

4. Coutinho JM, van den Berg R, Zuurbier SM, et al. Small juxtacortical hemorrhages in cerebral venous thrombosis. Ann Neurol 2014;75:908-916.

5. Ungersbock K, Heimann A, Kempski O. Cerebral blood flow alterations in a rat model of cerebral sinus thrombosis. Stroke 1993;24:563-569. 